\title{
The future of the Whistle-blowing Directive: criticising its legal bases
}

\author{
Dimitrios Kafteranis*
}

ABSTRACT The legal protection of whistle-blowers has recently received considerable attention from the legal community. Due to several scandals such as Luxleaks and Panama Papers, the legal status of whistle-blowers has become a starting point of discussion for governments, legal scholars, and regulators. In October 2019, the European Union took a significant step by adopting the Directive 2019/1937 on the protection of persons who report breaches of Union law. This Directive is significant as it is the first EU text offering protection to whistle-blowers at the EU level. This article will analyse the legal bases of the Directive and argue that the fragile nature of several of these bases means that they may be challenged before the Court of Justice of the European Union. Secondly, the goal of the article is to examine the role of the right to freedom of expression, as interpreted by the European Court of Human Rights, with respect to the Directive.

\section{Introduction}

Whistle-blowing has been increasingly present in the headlines: an old issue that has become topical again. ${ }^{1}$ Its reappearance in the European Union (EU) has resulted in changes to the law. ${ }^{2}$ Being unregulated for many years, whistle-blowing is now regulated by the recently adopted Directive 2019/1937 on the protection of persons who report breaches of Union law. ${ }^{3}$ Before its adoption, legislation in EU Member States was non-existent or

\footnotetext{
* PhD researcher, Faculty of Law, University of Luxembourg. Supported by the Luxembourg National Research Fund (FNR) - 10965388"/"Soutenu par le Fonds National de la Recherche, Luxembourg (FNR) - 10965388.

${ }^{1}$ Consider all the recent scandals: Panama Papers is the scandal of tax evasion revealed by the International Consortium of Investigative Journalists (ICIJ) showing that natural and moral persons were avoiding taxes by using offshore companies in Panama and other parts of the world. More information about Panama Papers can be found using the following link < https://panamapapers.icij.org/> accessed 21 April 2020.

Swissleaks is the scandal of tax evasion of private clients of the HSBC revealed by Hervé Falciani. More information about it can be found using the following link: The International Consortium of Investigative Journalists (ICIJ) < https://www.icij.org/project/swiss-leaks/explore-swiss-leaks-data> accessed 20 April 2020. Luxembourg Leaks (Luxleaks) is a scandal revealed by two ex-employees of PwC. The documents handed demonstrated that companies, in Luxembourg, had unjustified tax advantages. More information on: < https://www.icij.org/investigations/luxembourg-leaks/ > accessed on 30 April 2020.

Paradise Papers concerns the offshore activities of some of the world's most powerful people and companies $<$ https://www.icij.org/investigations/paradise-papers/ > accessed on 30 April 2020.

${ }^{2}$ For the present article, whistle-blowing will be defined as: "the disclosure by organizational members (former or current) of illegal, immoral or illegitimate practices under the control of their employers, to persons or organisations that may be able to effect action."

Janet P Near and Marcia P Miceli, 'Organizational of Dissidence: The Case of Whistle-blowing' (1985) 4 Journal of Business Ethics 1, 4.

${ }^{3}$ Commission Directive (EU) No 2019/1937 [2019] OJ L305/17 (Whistle-blowers Directive).
} 
inconsistent from one Member State to another, creating an uncertain and complex legal landscape for whistle-blowers in Europe. ${ }^{4}$

The genesis of EU legislation on whistle-blowing came with the support and efforts of the European Parliament which demanded that the European Commission propose legislation on the protection of whistle-blowers for a considerable period of time. ${ }^{5}$ The European Parliament initially demanded sector specific whistle-blowing provisions. Later the European Parliament began calling for a comprehensive legal framework on the protection of whistleblowers in every sector. ${ }^{6}$ Despite the importance of such legislative invitations to the European Commission, the responses were non-existent or limited to sectoral provisions on the protection of whistle-blowers. ${ }^{7}$ Under these sectoral provisions, whistle-blowers were not the central focus but were a means to achieve something in a specific area of EU concern. Certain sectoral provisions were indeed enacted by the EU legislature, but these provisions concerned, mostly, the banking and financial sector. ${ }^{8}$

This situation changed with the advent of a series of financial scandals that impacted European public opinion, such as Luxleaks and the Paradise Papers. ${ }^{9}$ At the time, there were varying levels of protection for these whistle-blowers which was dependent on the particular Member State. This signalled to the EU that it would be desirable to provide for a minimum standard of protection. Thus, the European Parliament passed the 2017 Resolution which

\footnotetext{
${ }^{4}$ European Commission, Commission Staff Working Document, Impact Assessment accompanying the document of the proposal for a Directive of the European Parliament and the Council on the protection of persons reporting on breaches of Union law $\operatorname{COM}(2018) 218$ final, 2

$<$ https://eur-lex.europa.eu/legal-content/EN/TXT/PDF/?uri=CELEX:52018SC0116\&from=EN $>$ Accessed 24 May 2020 (Commission's Impact Assessment).

${ }^{5}$ European Parliament, Resolution of 25 November 2015 on tax rulings and other measures similar in nature or effect (2015/2066(INI)), P8_TA(2015)0408, paras 144-145.

European Parliament, Resolution of 23 October 2013 on organised crime, corruption, and money laundering (2013/2107(INI)), P7 TA(2013)0444.

European Parliament, Resolution of 15 December 2011 on the mid-term review of the European strategy 20072012 on health and safety at work (2011/2147(INI)), P7_TA(2011)0589.

${ }^{6}$ As an illustration, the European Parliament had demanded whistle-blower protection in the framework of EU legislation related to the health and safety of employees. It was not to protect all whistle-blowers but the whistle-blower who reports health and safety issues in the workplace. The European Parliament abandoned the sectoral approach in the Resolution of $25^{\text {th }}$ November 2015 on tax rulings where it asked for horizontal whistleblowing legislation in which protect the whistle-blower in all sectors.

European Parliament, Resolution of 15 December 2011 on the mid-term review of the European strategy 2007 2012 on health and safety at work (2011/2147(INI)), P7_TA(2011)0589.

European Parliament, Resolution of 25 November 2015 on tax rulings and other measures similar in nature or effect (2015/2066(INI)), P8_TA(2015)0408, paras 144-145

${ }^{7}$ Simone White, 'A matter of life or death - whistleblowing legislation in the EU' (2018) 3 EUCRIM 170, 171 172.

${ }^{8}$ Commission Directive (EU) No 2014/57 [2014] OJ L173/179.

Commission Directive (EU) No 2015/849 [2015] OJ L141/73.

${ }^{9}$ See note 1 above.
} 
invited the European Commission to propose legislation on the protection of whistle-blowers at the EU level. ${ }^{10}$

Subsequently, the European Parliament demanded an EU horizontal legal framework. In response, the European Commission proposed legislation which would become the Directive on the protection of persons who report breaches of Union law. ${ }^{11}$ Seen by scholars and legislators as an enforcement tool or part of the right to freedom of expression, this Directive ensure that whistle-blowers can rely on EU legislation for his or her protection. ${ }^{12}$

The intervention of the EU is justified under two premises: first, the lack of harmonization at the EU and national level on legislation to protect whistle-blowers. The Directive aims to provide for minimum rules at the EU and national level to improve the enforcement of EU law in specific areas of EU interest. ${ }^{13}$ Second, the lack of coordination in relation to cross-border crime across the EU was identified as a problem by the European Commission. ${ }^{14}$ The fact that only certain countries had adopted legislation meant that whistleblower protection was at best a patchwork of member state legislation which was unhelpful for supressing cross-border crime.

According to the European Commission, the adoption of the Directive was necessary to set common minimum standards on the protection of whistle-blowers and initiate a change of culture. ${ }^{15}$ Apart from the legal developments of the Directive, the cultural perception of whistle-blowing may change due to the EU legal framework on the protection of whistleblowers. The EU Member States have often not regarded whistle-blowing as a positive activity but were frequently hostile to the concept. ${ }^{16}$ In the past, the passage of legislation has proved to affect cultural perceptions of whistle-blowing. ${ }^{17}$ The same expectations arise for the

\footnotetext{
${ }^{10}$ European Parliament Resolution of 24 October 2017 on legitimate measures to protect whistle-blowers acting in the public interest when disclosing the confidential information of companies and public bodies $(2016 / 2224(\mathrm{INI}))<$ http://www.europarl.europa.eu/sides/getDoc.do?type=TA\&language=EN\&reference=P8TA-2017-0402> accessed on 23 May 2020 (Parliament's Resolution).

The Resolution differed from previous iterations as it only related to the protection of whistle-blowers generally.

${ }^{11}$ European Commission, Proposal for a Directive of the European Parliament and of the Council on the protection of persons reporting breaches of Union law $\operatorname{COM}(2018) 218$ final < https://ec.europa.eu/info/sites/info/files/placeholder_8.pdf > accessed 23 May 2020 (Commission's Proposal). Commission Directive (EU) No 2019/1937 [2019] OJ L305/17 (Whistle-blowers Directive).

${ }^{12}$ Dimitrios Kafteranis, 'A new enforcement tool: a Directive to protect whistle-blowers' (2020) 41 Business Law Review 50

${ }^{13}$ Commission's Impact Assessment, 30.

14 ibid 3.

15 ibid 32 .

${ }^{16}$ Robert G. Vaughn, The successes and failures of whistleblower laws (EE publications: 2012) pp. 253-255

${ }^{17}$ James Gobert and Maurice Punch, 'Whistleblowers, the Public Interest and the Public Interest Disclosure Act 1998' (2000) 63 The Modern Law Review 25, 50-53
} 
Directive on the protection of persons who report breaches of Union law and its cultural impact. $^{18}$

This is the first EU legal text aiming to protect whistle-blowers in a pan-sectoral way. ${ }^{19}$ This pan-sectoral approach means that the Directive protects whistle-blowing in areas of EU interest but it does not entail all areas. Furthermore, unlike the most Directives which are often adopted on a single legal basis, this Directive was adopted on twelve separate legal bases. ${ }^{20}$ This atypical circumstance led to lengthy and important debate amongst the actors involved with the negotiations. Firstly, the Lisbon Treaty does not contain a stand-alone legal basis on which the European Commission could have proposed the Directive. ${ }^{21}$ To overcome this problem, the European Commission proposed the Directive on several legal bases, as permitted by the case law of the Court of Justice of the European Union (CJEU). ${ }^{22}$

However, the central legal basis of the Directive is article 114 of the Treaty on the functioning of the EU (TFEU) which regards the protection of the internal market. ${ }^{23}$ The adoption of article 114 as the main legal basis illustrates that the intended focus of the Directive is to protect the internal market. It follows that the other articles included as legal bases are areas where whistle-blowing is necessary and complementary to the protection of internal market. Significantly, the Directive excluded articles that are inherently connected to the protection of reporting persons such as article 153 TFEU and article 11 of the Charter of Fundamental Rights (CFR - the right to freedom of expression) as legal bases.

The overall aim of this article is to provide critical remarks about the choice of legal bases and to examine the right of freedom of expression in relation to whistle-blowers. First, the choice of certain legal bases is scrutinised and analysed. The fact that certain legal bases

\footnotetext{
${ }^{18}$ Whistle-blowers Directive.

${ }^{19}$ Council of the European Union, Opinion of the legal service on the legal basis for the proposal for a directive on the protection of persons reporting on breaches of Union law (2018) JUR_14620/18, p 2. The Legal Service of the Council characterises it as a cumulative sectoral approach or an "omnibus" approach.

${ }^{20}$ The twelve legal bases are: articles 16, 43(2), 50, 53(1), 91, 100, 114, 168(4), 192(1) and 325(4) Treaty on the Functioning of the EU and article 31 of the Treaty establishing the European Atomic Energy Community ${ }^{21}$ Commission's Impact Assessment, 31.

${ }^{22}$ Case C- 440/05 Commission v. Council [2007] E.C.R. I-9097; Case C-411/06 Commission v. Parliament and Council [2009] ECR I-7585, Case C-411/06 Commission v. Parliament and Council [2009] ECR I-7585, paras 46-47, Opinion 2/00 Cartagena Protocol on Biosafety [2001] EU:C:2001:664, p I-9722, Case C-155/07 Parliament v. Council [2008] EU:C:2008:605, para 37, Case C-166\&07 Parliament v. Council [2009] EU:C:2009:499, paras 68-69

${ }^{23}$ Consolidated versions of the Treaty on European Union and the Treaty on the Functioning of the European Union (TFEU) [2016] OJ C202/1

Vigjilenca Abazi, 'The European Union Whistleblower Directive: A 'Game Changer' for Whistleblowing Protection?' (2020) Industrial Law Journal 1, 7.
} 
were refused on procedural grounds without further analysis raises challenges the alleged purpose of the Directive, to protect the whistle-blower or the interests of the EU. Second, the role of the right to freedom of expression will be analysed. This analysis will assess contradictions in the EU approach to the protection of whistle-blowers with the established case law of the European Court of Human Rights on the protection of reporting persons. Finally, this article is timely because the transposition of the Directive is ongoing and the articles addresses the Directive from a new scholarly perspective, its legal bases.

\section{Pandora's box: The legal basis}

The European Parliament's Resolution did not provide extensive analysis on the legal basis of the Directive, ${ }^{24}$ instead, it invited the European Commission to propose a Directive providing global protection for whistle-blowers in every sector. ${ }^{25}$ In response, the European Commission's stated that it would not be possible to propose an EU legal framework that will protect whistle-blowers globally as it does not have a legal basis or bases that support it. ${ }^{26}$ It opted for a pan-sectoral EU legal framework in which the whistle-bower will be protected under EU law in different areas of EU interest. To that end, the proposal for a Directive, as presented by the European Commission, had seventeen different legal bases. ${ }^{27}$ This was quite an unusual number of legal basis as normally EU legislative acts are based on a single or dual number of legal bases. ${ }^{28}$ However, following negotiations between the European Parliament and the Council, the Directive was adopted on twelve separate legal foundations. The first part of this article will examine the decision to adopt twelve separate legal bases and the following parts (B-E) will comment on the most significant articles of the TFEU related to whistleblowers' protection, articles 113,114, 115 and 153 TFEU.

\subsection{Multiple legal bases: Why was the decision taken?}

\footnotetext{
${ }^{24}$ Parliament's Resolution, para 1. The European Parliament had only mentioned that "there are at present several possibilities for legal bases enabling the EU to take action on the matter [...] reminds the Commission of the doctrine elaborated by the CJEU, through long-standing case-law, on the concept of implied competences of the Union, which allows the use of several legal bases". No further points have been made by the European Parliament in its Resolution.

${ }^{25}$ Parliament's Resolution, para 1.

${ }^{26}$ Emanuela Andreis, 'Towards common minimum standards for whistleblower protection across the EU' (2019) 4(2) European Papers 575, 577-578 < http://www.europeanpapers.eu/en/europeanforum/towards-commonminimum-standards-for-whistleblower-protection-across-eu $>$ accessed 23 May 2020.

${ }^{27}$ Commission's Proposal, 5-6.

${ }^{28}$ Annegret Engel, The Choice of Legal Basis for Acts of the European Union (Springer 2018) 83.
} 
The European Commission stated in the Impact Assessment on the proposed Directive that the Treaties do not provide a legal basis which would allow the regulation of whistleblower protection in general. ${ }^{29}$ In addition, the Commission found that the right to the freedom of expression as described in article 11 of the Charter of Fundamental Rights cannot serve as a standalone legal basis, stating that regardless the Directive will have a positive impact on the right to freedom of expression and other rights. ${ }^{30}$ Other solutions, such as the field of fraud and corruption, could also not provide a self-standing legal basis for the adoption of a horizontal EU legal act on the protection of whistle-blowers. ${ }^{31}$

The European Commission was in a difficult position. On the one hand, it had to respond to the European Parliament to strengthen protection. On the other hand, it had no legal basis for harmonisation legislation. As a result, it concluded that a horizontal EU legal act could not be adopted given the absence of a provision in the Treaties allowing it. Instead, it proposed a different solution. It identified certain EU sectors such as the financial markets and the protection of the environment where the EU rules were under enforced. In those sectors, the EU had previously adopted rules at the national level, but there was a lack of enforcement. Introducing whistle-blowing legislation in these sectors aimed to provide a tool for national authorities to better enforce EU rules. ${ }^{32}$ The European Commission decided to combine the legal bases that correspond to the sectors, to propose legislation on the protection of whistleblowers in a pan sectoral way and to ensure that minimum standards will be enforced. ${ }^{33}$

The Directive was adopted on the legal bases of eleven articles of the TFEU and one article of the Treaty establishing the European Atomic Energy Community. ${ }^{34}$ The opinion of the Legal Committee of the European Parliament, along with the opinion of the Legal Service of the Council, was of great interest and importance to the discussion on legal bases. The first

\footnotetext{
${ }^{29}$ Commission's Impact Assessment, 30.

${ }^{30} \mathrm{ibid}, 31$.

${ }^{31}$ Commission's Impact Assessment, 31.

${ }^{32}$ Commission's Proposal, 2-3.

Roland Bieber and Francesco Maiani, 'Enhancing centralised enforcement of EU law: Pandora's toolbox?' (2014) 51 Common Market Law Review 1057, 1058.

${ }^{33}$ In addition, there is a dilemma to the Member States now as to the transposition of the Directive. If a Member State transposes the Directive, certain sectors stay outside the reach of the Directive, thus are related to national law. This means that this State will have two legislations on whistle-blowing: one covering the Directive and one covering the other sectors. As this situation may be problematic in terms of clarity of national laws, Member States may decide to transpose the Directive, cover all sector and create a unique national law on the protection of whistle-blowers. In that way, the European Commission can have a horizontal approach as asked by the European Parliament.

${ }^{34}$ Whistle-blowers Directive.
} 
point of agreement between the Committees was that the European Commission could propose legislation based on several legal foundations. ${ }^{35}$ The use of multiple legal foundations is justified when done in exceptional circumstances that require a demonstration that the measure in question pursues simultaneously multiple legal objectives of equal weight. ${ }^{36}$ This view has been confirmed by the CJEU which states:

"If examination of a Community measure reveals that it pursues a twofold purpose or that it has a twofold component and if one of those is identifiable as the main or predominant purpose or component, whereas the other is merely incidental, the act must be based on a single legal basis, namely that required by the main or predominant purpose or component [...]. Exceptionally, if on the other hand it is established that the act simultaneously pursues many objectives or has several components that are indissociably linked, without one being secondary and indirect in relation to the other, such an act will have to be founded on the various corresponding legal bases (...)." 37

In addition, the CJEU has acknowledged that the combination of numerous legal bases is possible when they are indissociably linked, without one being secondary and indirect in relation to the other, if they do not entail incompatible decision-making procedures. ${ }^{38}$ It is important to analyse the choice to include certain Treaty articles because an incorrect legal basis constitutes a procedural defect capable of rendering a decision related to the Directive as invalid. ${ }^{39}$

\subsection{Excluding labour rights and the protection of workers: article $153 \mathrm{TFEU}$}

\footnotetext{
${ }^{35}$ European Parliament, Committee on Legal Affairs, Opinion on the legal basis for the proposal for a directive on the protection of persons reporting on breaches of Union law (2018) JURI_AL(2018)629554 (Parliament's Legal Affairs Committee).

Council of the European Union, Opinion of the legal service on the legal basis for the proposal for a directive on the protection of persons reporting on breaches of Union law (2018) JUR_14620/18 (Council's Legal Service).

${ }^{36}$ Council of the European Union, Opinion of the legal service on the legal basis for the proposal for a directive on the protection of persons reporting on breaches of Union law (2018) JUR_14620/18, p 7

${ }^{37}$ C-336/00 Republik Osterreich v Martin Huber [2002] ECR I-07699, para 31; C-338/01 Commission v Council [2004] ECR I-04829, paras 55 et seq.; Case C-411/06 Commission v Parliament and Council [2009] ECR I07585, paras 46 and 47; C-155/07 Parliament $v$ Council [2008] ECR I-08103, paras 36 et seq.

${ }^{38}$ C-155/07 Parliament v Council [2008] ECR I-08103, para 37.

39 CJEU, Opinion pursuant to article 300 EC, Opinion of the Court, Opinion 2/00, 6 December 2001, ECLI:EU:C:2001:664.
} 
One of the first articles considered for the adoption of the proposed Directive was article 153 TFEU. This article provides some areas of social policy where the EU can complement and support the activities of the Member States. ${ }^{40}$ More specifically, this provision is related to the working conditions of employees with a particular focus on health and safety. The Economic and Social Committee invited the European Commission to include this article in the proposal due to its interest in the protection of workers. ${ }^{41}$ The European Commission examined the possibility of including this article but ultimately excluded it. ${ }^{42}$ According to the European Commission, while the article aims to promote the protection of employees, the personal scope would have been very limited, as whistle-blowing would have inherently been focused on issues related to the health and safety of workers only. ${ }^{43}$

Under this article, the protection of the whistle-blower would have been limited because it would have required the disclosure to relate to the protection of the health and safety of the employees in the workplace, an area which is already regulated at the EU level. ${ }^{44}$ Focusing only on the health and safety of workers would have limited the role of the Directive and the protection offered to whistle-blowers. While adopting article 153 as a legal base would result in work-related grievances being reported, it was not likely to capture 'pure' whistle-blowing disclosures with a cross-border dimension and possible spill-over impact as the Directive intended. ${ }^{45}$

Despite the logical reasoning of the European Commission concerning the exclusion of article 153 TFEU, it is surprising that a Directive on the protection of whistle-blowers (employees) will not have as a legal basis the Treaty article that refers to labour law. An explanation of the non-inclusion of article 153 TFEU as a legal basis may be that labour law and protection of labour rights remains a national competence. Nevertheless, the protection of the whistle-blower is related to the working conditions and the inclusion of the article would have been a positive symbolism towards the need to protect the employee and not only the market.

\footnotetext{
${ }^{40}$ Sacha Garben, article 153-156 in Manuel Kellerbauer, Marcus Klamert and Jonathan Tomkin (eds.)

Commentary on the EU Treaties and the Charter of Fundamental Rights (OUP, 2019) 1638-1639

${ }^{41}$ European Economic and Social Committee Opinion of 18 October 2018 on strengthening whistle- blower protection at EU level.

${ }^{42}$ Commission's Impact Assessment, 38.

${ }^{43}$ ibid.

${ }^{44}$ Commission's Impact Assessment, 38.

${ }^{45}$ Andreis (n 26) 577-578.
} 
The Directive's main objective is protecting the internal market and the EU's interests, setting aside labour rights which directly concern the employee as a reporting person. It is antithetical that while article 153 TFEU was not used as a legal basis, the Directive obliges the European Commission to review whether to expand the scope of the Directive by including working conditions in $2023 .{ }^{46}$ This obligation leaves the impression that the exclusion of article 153 TFEU was ill-considered during the negotiations and the problem-solving is transferred to the near future.

\subsection{Protecting the internal market: the use of article 114 TFEU}

As a main legal basis, the European Commission's proposal relied on article 114 TFEU. ${ }^{47}$ The CJEU has argued in its case-law, inter alia, that a measure adopted under article 114 TFEU should have as its object the establishment and functioning of the internal market. ${ }^{48}$ In particular, the measures that will be adopted should have the intention of improving the conditions for the establishment and functioning of the internal market and contributing to the elimination of obstacles to the freedom of providing services or to the free movement of goods. ${ }^{49}$

In recital 4 of the European Commission's proposal, the European Commission emphasised the fragmented nature of whistle-blower protection at national and EU level. ${ }^{50}$ Further, that the lacking protection had major negative consequences for reporting, and thus, the actual protection of whistle-blowers and the proper functioning of the internal market. ${ }^{51} \mathrm{In}$ addition to clear the distortion in competition, with the possible spill-overs across national borders in different policy areas, the European Commission claimed that the fragmented protection available for whistle-blowers was the principal justification for using article 114 TFEU. ${ }^{52}$

Nevertheless, article 114 TFEU could not stand alone as a sufficient legal basis for the entire proposal as it could not be used alone to enhance the enforcement of Union law when

\footnotetext{
${ }^{46}$ Whistle-blowers Directive, art. 27(3). The Directive will be reviewed in 2023 and amendments will be proposed by 2025 the latest.

${ }^{47}$ Commission's Proposal, recital 81.

${ }^{48}$ C-270/12 United Kingdom v European Parliament and Council [2014] EU:C:2014:18, para 11.

${ }^{49} \mathrm{C}-270 / 12$, n 44 , para 11

${ }^{50}$ Commission's proposal, recital 4.

51 ibid.

52 ibid., recitals $4,6,10,13,14$ and 81 .
} 
there are more appropriate articles in the Treaties. ${ }^{53}$ The protection of the internal market is one of the purposes of the Directive but for the protection of other sectors of EU interest such as transport safety and product safety, TFEU entails specific articles that should be used along with article 114 TFEU. ${ }^{54}$

\subsection{Workers or the internal market?}

The issue of adopting the Directive either on the internal market legal basis (article 114 TFEU) or the protection of workers (article 153 TFEU) needs to be scrutinised in more detail. Article 114 TFEU is considered as the article that promotes the economic integration of the Union and minimises any negative impact on economic activity and economic actors. ${ }^{55}$ Certainly, the enhancement of EU social and labour policy is the result of regulating the internal market. ${ }^{56}$ The advancement of the internal market brings together advancements in labour market regulation and social policy. Nevertheless, there is no systematic or comprehensive EU social policy, it is fragmented and on an ad hoc basis. ${ }^{57}$ Non-economic interests are not central, but peripheral to the internal market. ${ }^{58}$ In the Directive on the protection of whistle-blowers, article 114 TFEU is considered the central legal basis around which other legal bases are used, ${ }^{59}$ whereas article 153 TFEU was discarded for the reasons explained above. Thus, it seems that the protection of the internal market triumphs over the social dimension of the protection of whistle-blowers.

Two issues flow from this hypothesis. First, it is understood that by adopting article 114 TFEU as the main legal basis, the priority seems to be given to the market and not the employee. Certainty, protection is granted to the whistle-blower under the Directive but in a possible dispute between the employee and the employer, priority could be given to the employer (the market) and not to the employee. ${ }^{60}$ For instance, if a dispute arises between the whistle-blower and the employer, before a national or European Court, the employer may

\footnotetext{
${ }^{53}$ Council's Legal Service, 14.

54 ibid.

For public health, article 168(4) TFEU. For transport and product safety, articles 91 and 100 TFEU. For the protection of animal welfare, article 43(2) TFEU. For the protection of the environment, article 192(1).

55 Gareth Davies, 'Democracy and Legitimacy in the Shadow of Purposive Competence' (2015) 21(1) European Law Journal 2, 10.

${ }^{56}$ Stephen Weatherill, The Internal Market as a Legal Concept (OUP, 2017) 205.

57 Ibid. 204

58 ibid.

${ }^{59}$ Abazi (n 23) 7.

${ }^{60}$ The abstraction made is that the market relates to the employer who may be a corporation or a company or an institution that has power over the employee (the whistle-blower). The employer represents the market interests whereas the whistle-blower is the weak part which may go against the market interests.
} 
receive a stronger level of protection than the employee. This point may be the result of a teleological interpretation of the Directive. If the judges, in a particular case, decide that the "telos" of the Directive is to protect the market, they may refuse to protect the whistle-blower and decide to protect the employer. ${ }^{61}$ As Weatherill notes, 'Any argument that the Court is not locked into a congenital tendency to prioritize economic rights over social and political rights must reckon with the abominable December 2017 rulings of the Grand Chamber of the Court of Justice in Viking Line and Laval, ${ }^{62}$

Second, whistle-blowing is an issue with societal and cultural implications. ${ }^{63} \mathrm{By}$ selecting to legislate primarily on the basis of article $114 \mathrm{TFEU}$, the emphasis is given to the economic implications of whistle-blowing while partially ignoring the social legitimacy and the acceptance of EU legislation and institutions by the citizens. ${ }^{64}$ Even if we accept that the construction of the internal market allows the enhancement of labour rights and the definition of the internal market captures more than economic integration, it does not mean that the priority is on labour rights and not the internal market. Certainly, this is decided ad hoc by the CJEU and until now its approach is more favourable to economic integration rather than labour rights. If article 153 TFEU had been used, the emphasis would have been to the citizens and employees rather than the market. The EU legislator would have demonstrated that the priority is over the protection of employees and the security of their labour rights. By selecting article 114 TFEU, the focus tilts from society towards the protection of the internal market.

\subsection{Tax related reporting and articles 113 and 115 TFEU}

The Directive also includes other areas of EU interest such as corporate tax policies. ${ }^{65}$ During the Directive's negotiations, the Legal Service of the Council stated that the whistleblower could report issues related to corporate tax avoidance/evasion. ${ }^{66}$ The problem was that taxation measures could be adopted under articles 113 or 115 TFEU, which demand a special

\footnotetext{
${ }^{61}$ The internal market as a legal concept is ambiguously attached to this incrementally-shaped pattern of social policy as Weatherill argues. In a subsequent case, the EU judges should balance the need to protect the internal market with the need to enhance labour rights. The fact that social and labour policy are parts of the internal market does not assure that the latter will prevail to the former in a possible case in front of the Court.

See Stephen Weatherill, The Internal Market as a Legal Concept (OUP, 2017) 125 and 204

${ }^{62}$ Weatherill (n 56) 125.

Case C-438/05, International Transport Workers' Federation v. Viking Line ABP, [2007] ECR I-10779 (ECLI:EU:C:2007:772); Case C-341/05, Laval un Partneri, [2007] ECR I-11767 (ECLI:EU:C:2007:809).

${ }^{63}$ Stelios Andreadakis, 'Enhancing Whistleblower protection: It's all about the Culture' (2019) 30(6) European Business Law Review 859, 860.

${ }^{64}$ Davies (n 55) 2.

${ }^{65}$ Whistle-blowers Directive, recital 18 and art. 2(1)(c)

${ }^{66}$ Council's Legal Service, 22.
} 
legislative procedure requiring unanimity in the Council and the consultation of the European Parliament. ${ }^{67}$

The Legal Service of the Council argued that a different EU legal act should be proposed under articles 113 or 115 TFEU to ensure that reporting corporate tax practices, which can be abusive, would have the correct legal basis. ${ }^{68}$ This was also the view of the UK government's committee that issued an opinion on the proposal. ${ }^{69}$ The Committee highlighted that tax related measures concern the Member States and should be decided unanimously to respect Member States' sovereignty. ${ }^{70}$

Despite this discussion on the correct legal basis for adopting tax law related measures, the Directive did not make any reference to the articles 113 or 115 TFEU as they would have been procedurally incompatible with the scope of tax whistle-blowing under the existing legal basis. $^{71}$ The European Commission overcame this problem by omitting articles 113 and 115 TFEU that require unanimity and using instead article 114 TFEU, which does not require unanimity.

\subsection{Conclusion}

This section of the article analysed the legal bases of the Directive and analysed certain problematic aspects related to the choice of articles. The negotiations of the Directive should have encompassed articles 113, 115 and 153 TFEU as legal bases of the Directive. Further, the negotiations should have found a way to overcome the obstacles described above. An better solution would have been to adopt different EU legal acts on the protection of whistle-blowers depending on the sector and the article(s) used as a legal basis. This would have avoided the fragmented sector specific approach of the Directive and provided legislation in every sector, resulting in a horizontal approach. While this approach may have been more time-consuming, there would be fewer uncertainties regarding the legality of the legislation.

\footnotetext{
${ }^{67}$ Manuel Kellerbauer, Article 113-115 in Manuel Kellerbauer, Marcus Klamert and Jonathan Tomkin (eds.) Commentary on the EU Treaties and the Charter of Fundamental Rights (OUP, 2019) 1229.

68 ibid.

${ }^{69}$ Parliament of the United Kingdom, European Security Committee, Whistleblowing and breaches of EU law (2019), point $1.9<$ https://publications.parliament.uk/pa/cm201719/cmselect/cmeuleg/301-lxx/30104.htm > accessed 25 May 2020

${ }^{70}$ ibid.

${ }^{71}$ Council's Legal Service, 23
} 
Article 114 TFEU, in conjunction with articles 43(2), 91, 100, 168(4), 192(1) and 325 TFEU, would have been a better legal basis for a Directive on the protection of whistle-blowers. Then specific issues, such as tax whistle-blowing or criminal law measures, should have been adopted under the relevant legal bases and procedures. Adopting the Directive on several legal bases may also be proven problematic if a preliminary ruling is requested before the CJEU. ${ }^{72}$ Member States may challenge the legality of the Directive based on the exclusion of articles which seemed necessary to support the areas covered by the Directive (see tax issues). If the CJEU agrees, the Directive must be modified and could result in more comprehensive protection fort whistle-blowers through. In such an event, clear and more straightforward legal bases would bring stability to the Directive and the whistle-blowers it seeks to protect.

The last remark concerns the issue of enforcement and effectiveness at the EU level. The EU does not have any competence of enforcement due to its limited powers of enforcement. ${ }^{73}$ In the absence of a specific delegation of enforcement powers to the EU, ${ }^{74}$ enforcement is within a Member State's role. ${ }^{75}$ On the contrary, the effectiveness of EU law is upon the EU. Thus, it is peculiar to base EU legislation on the protection of whistle-blowers on the need to better enforce EU law when enforcement is not clearly under EU's purview. It may be the case that this Directive underlines the need for a debate on revisiting the legal bases of enforcement to empower the enforcement competence of the EU. As the Directive has only recently been adopted, it is not unlikely that a case will appear before the CJEU challenging the legal basis and the Directive's enforcement character.

\section{Freedom of expression and blowing the whistle}

Whistle-blowing is considered as an exercise of the right of the freedom of expression. ${ }^{76}$ The protection of the whistle-blower, under his or her right to the freedom of expression, is a long standing fundamental principle in the Council of Europe and the European Court of Human Rights. ${ }^{77}$ Even if whistle-blowing is considered to be the expression of an unpopular

\footnotetext{
72 Abazi (n 23) 15.

${ }^{73}$ Stine Andersen, The Enforcement of EU Law (OUP, 2012) 42.

${ }^{74}$ Herwig C. H. Hofmann, Gerard C. Rowe and Alexander H. Turk, Administrative Law and Policy of the European Union (OUP, 2011) 691.

${ }^{75}$ Uglijesa Grusic, 'The principle of effectiveness in European law and European private international law: the case of transnational employment in the European Court of Justice and English courts' in J-S Bergé and others (eds), Boundaries of European Private International Law (Bruylant 2015) 430.

${ }^{76}$ Wim Vandekerckhove, Freedom of expression as the broken promise of whistleblower protection, (2016) 10 La Revue des droits de l'homme. para 31.

${ }^{77}$ William Schabas, The European Convention on Human Rights - A Commentary (OUP, 2015) 465.
} 
opinion or a breach of secrecy, it is indisputable that the employee or the person who reports, is exercising his or her freedom of expression. The connection of whistle-blowing with the right to freedom of expression has been addressed by the Council of Europe through its enforcement organ, the European Court of Human Rights. ${ }^{78}$ The Council of Europe has adopted different instruments aiming at the effective protection of whistle-blowers based on article 10 of the European Convention of Human Rights (ECHR) ${ }^{79}$ Similarly, the European Court of Human Rights has established case-law on the protection of whistle-blowers under article 10 ECHR. Therefore, whistle-blowing enjoys established protection as a form of protected free speech. ${ }^{80}$

During the discussions surrounding the adoption of the Directive, inspiration was drawn from the right to freedom of expression as enshrined in article 11 of the European Charter of Fundamental Rights and article 10 ECHR. ${ }^{81}$ As aforementioned, article 11 of the Charter could not be a self-standing legal basis for the adoption of the Directive. ${ }^{82}$ Nevertheless, the inspiration of the EU from the Council of Europe and the European Court of Human Rights and the provisions of the Directive are conflicting with the approaches of the European Court of Human Rights in several reprisals.

Despite the conflicting approaches, the European Commission highlighted that all policy options regarding the protection of whistle-blowers will have a positive impact on the freedom of expression, which is recognised as a fundamental right in the Charter. ${ }^{83}$ The lack of sufficient protection of the whistle-blower across the EU before the adoption of the Directive negatively impacted the public's right to access information, media, and freedom of expression. By adopting the Directive, the EU demonstrates its intent to provide legal certainty and strengthen the protection of the right to freedom of expression.

The analysis of the European Court of Human Rights jurisprudence is essential as it deals directly with the interpretation of the Directive. Given the mutual respect that the CJEU and the European Court of Human Rights have to each other, the ECHR case law would

\footnotetext{
${ }^{78}$ Guja v Moldova (Application No 14277/04) (2008) ECHR 144.

${ }^{79}$ Recommendation CM/Rec(2014)7, Protection of whistle-blowers, adopted by the Committee of Ministers of the Council of Europe, 30 April 2014.

${ }^{80}$ Draft Directive on whistle-blower protection in the public and private sector in the European Union, proposed by the Greens/EFA parliamentary group to the European Commission, 4 May 2016.

${ }^{81}$ Commission's Impact Assessment, 47.

82 Commission's Impact Assessment, 30-31

83 ibid.
} 
certainly be brought in front of the CJEU in a future dispute. At this point, it is interesting to briefly discuss the case law of the European Court of Human Rights to analyse the different approach taken by the European Court of Human Rights and the Directive and to examine the consequences it may have for whistle-blowers' protection.

The European Court of Human Rights, in its landmark decision on Guja v. Moldova, granted protection to a whistle-blower under article 10 ECHR. ${ }^{84}$ In this case, the Court established six criteria that should be examined by national jurisdictions in determining whether to grant protection for whistle-blowers under article 10 of the Convention (right to freedom of expression). ${ }^{85}$ The Court in subsequent cases such as Bucur and Toma and Heinisch $^{86}$, confirmed these criteria which are cumulative and require a case-by-case analysis. 87

The Guja case was important, as it was the first to grant protection to the whistle-blower on a European level. Specifically, the Guja case concerned a Moldovan public servant, working as the Head of the Press Department of the Prosecutor General's Office, who discovered certain illegalities and then reported them. ${ }^{88} \mathrm{Mr}$. Guja was subsequently dismissed and after exhausting the available remedies, ${ }^{89}$ he brought his claim in front of the European Court of Human Rights asking for protection under article 10 ECHR.

The first criterion out of the six established by the Court for the protection of whistleblowers is linked to the means of disclosing the information. Initially, the information should be disclosed internally to a superior or competent authority or body. If this is impossible, only then the information can be disclosed to the public as an ultima ratio, or last solution. ${ }^{90}$

\footnotetext{
${ }^{84}$ Guja v Moldova (n 78).

${ }^{85}$ Council of Europe, Convention for the Protection of Human Rights and Fundamental Freedoms (European Convention on Human Rights, as amended) (ECHR) art. 10.

${ }^{86}$ Heinisch v Germany (Application No 28274/08) (2014) 58 E.H.R.R. 31.

Bucur and Toma v Romania (Application No 40238/02) (2013) ECHR 14.

Valerie Junod, 'Lancer l'alerte: quoi de neuf depuis "Guja"?: (Cour eur. dr. h., "Bucur et Toma c. Roumanie", 8 janvier 2013)' (2014) 98 Revue trimestrielle des droits de l'homme 459.

87 Junod (n 76).

${ }^{88}$ Guja v Moldova (n 78) para 12.

${ }^{89}$ Mr. Guja brought a civil action against the Prosecutor General's Office seeking reinstatement in 2003. The Chisinau Court of Appeal dismissed his action. Mr Guja appealed but the Supreme Court of Justice dismissed his appeal.

${ }^{90}$ Guja v Moldova (n 78) para 73.
} 
The second criterion concerns the public interest in the information disclosed. ${ }^{91}$ The Court confirmed that: "The interest which the public may have in particular information can sometimes be so strong as to override even a legally imposed duty of confidence." 92 The European Court of Human Rights follows a balanced approach as to the duty of loyalty, which public servants should respect, and to the public interest character of the information. If the public interest of the information is strong, then it can override the duty of loyalty.

The next criterion is the authenticity of the information revealed. ${ }^{93}$ The Court added this criterion to avoid defamatory or bad faith accusations and noted that the right to freedom of expression carries obligations and responsibilities. ${ }^{94}$ Minding the requirement to avoid defamatory or bad faith accusations, the person giving the information should ensure its authenticity to the highest extent possible.

The fourth criterion is to weigh the damage suffered by the public authority resulting from the disclosure and assess whether it outweighs the public interest in the information. ${ }^{95}$ The Court again took into consideration the interests and the image of the public authority (or the private entity if it concerns the private sector). Following this direction, the Court directed national courts to balance the proportionality of the information revealed concerning the public interest and the damage suffered by the relevant entity, public or private.

The fifth criterion states that the individual should disclose in good faith. The bona fide whistle-blower must act in the public interest and believe that the information disclosed was accurate. ${ }^{96}$ The Court excluded whistle-blowers from this protection when they acted in bad faith, stating that their motivation was based on personal advantage, financial expectation, or personal antagonism. ${ }^{97}$

The last criterion is related to the sanction imposed on the whistle-blower and its consequences on the individual. The Court emphasised that this criterion is linked to the proportionality of the interference in relation to the legitimate aim pursued..$^{98}$ Thus, it must be

\footnotetext{
91 ibid. para 74.

92 ibid.

${ }^{93}$ Guja v Moldova (n 78) para 75.

94 ibid.

95 ibid. para 76.

96 Ibid. para 77.

97 ibid.

98 ibid. para 78.
} 
determined whether the sanction imposed is proportionate to the severity of negative consequences for the whistle-blower. To conclude, the European Court of Human Rights effectuates a balance of potentially competing interests to protect the whistle-blower's freedom of expression.

The Directive drew inspiration from this jurisprudence and the principles resulting from the approach of the European Court of Human Rights. ${ }^{99}$ Although the Directive respects the right to the freedom of expression, it focuses on the enforcement role of the whistle-blower. Given the problematic nature of the enforcement of EU law, the intention was to create new rules on protecting persons that would enhance the respect of EU rules by reporting when wrongdoing occurs.

The approach of the Directive attributes a 'managerial' character to whistle-blowing whereas the European Court of Human Rights approach attributes a 'democratic' character to whistle-blowing. ${ }^{100}$ For the EU, the focus is the protection of the internal market and the financial interests of the EU, while respecting the freedom of expression is of secondary importance. In contrast, it appears that the European Court of Human Rights intended to protect whistle-blowers based on their right to the freedom of expression. ${ }^{101}$ It is apparent that, while the EU Directive has a business/economic driven motivation, the European Court of Human Rights has a human rights motivation. This does not define the protection as more or less effective in either approach but elucidates the different motivations by which future conclusions may be reached by the two Courts. The CJEU will have to emphasize the protection of the market, whereas the European Court of Human Rights emphasises the protection of the right to freedom of expression.

A paradoxical situation is thus created when considering the two approaches to applying protection for the whistle-blower. Despite the inspiration that the EU has taken from the Council of Europe and the case law of the European Court of Human Rights, ${ }^{102}$ there are certain points which may prove that the CJEU will protect a whistle-blower in a situation where

\footnotetext{
${ }^{99}$ Whistle-blowers Directive, recital 31.

${ }^{100}$ Jean-Philippe Foegle, 'Le lanceur d'alerte dans l'Union Européenne: démocratie, management, vulnérabilité' in Mathieu Disant and Delphine Pollet-Panousis (eds), Les lanceurs d'alerte (LGDJ éd. 2017) 107-120.

${ }^{101}$ William Schabas, The European Convention on Human Rights - A Commentary (OUP, 2015) 465

102 Commission's Impact assessment, 33.
} 
the European Court of Human Rights will not. ${ }^{103}$ First, the European Court of Human Rights requires that the whistle-blower reported in good faith, whilst the Directive does not contain such a criterion. Second, the European Court of Human Rights requires that the whistle-blower first reports internally before going to the competent authorities. On this point, the Directive gives the whistle-blower the option to choose whether he or she will report internally or to the relevant authorities first. Furthermore, the Directive invites the whistle-blower to report even if he or she has suspicions of wrongdoing, whereas the European Court of Human Rights asks the whistle-blower to check the authenticity of the information to ensure that there is a wrongdoing.

The Directive has a lower threshold for granting whistle-blower protection than the European Court of Human Rights. This conflicting situation may lead to a situation in which the whistle-blower will be protected under EU law but will not be able to meet the criteria for protection according to the jurisprudence of the European Court of Human Rights and vice versa.

\section{Concluding remarks}

The Directive was adopted on multiple legal bases. This was captured by the debate concerning articles 113,114, 115 and 153 TFEU and the relation of the Directive with the right to freedom of expression as interpreted by the European Court of Human Rights. At first, the fact that numerous legal bases were used for the adoption of this legal instrument is significant and raises questions as to the viability and legality of the Directive. The focus of the Directive on the protection of the internal market, rather than the protection of workers or legal bases which will promote social cohesion and avoid legal tensions, may void the text from its purpose: to effectively protect the employee. The Directive protects the whistle-blower only when information related to market wrongdoings are provided, and leaves unprotected the whistle-blower who reports wrongdoings related to working conditions and labour rights. While the Directive is welcome legislation, the critical remarks provided in this article on its legal foundations demonstrate that more consideration should have been given by the EU to the theoretical foundations of the Directive.

\footnotetext{
${ }^{103}$ Dimitrios Kafteranis and Robert Brockhaus, 'Time to reconsider Strasbourg's whistleblower case law' (2020) European Law Blog, available on: < https://europeanlawblog.eu/author/kafteranis-dimitrios/ $>$ accessed on 23 November 2020.
} 
In addition, the article analyses the relationship between the provisions of the Directive and the principles of whistle-blowers protection under the right to freedom of expression as established by the European Court of Human Rights. The EU inspired the Directive's provisions from the case law of the European Court of Human Rights. The final text, though, has several different points than the criteria for protection of whistle-blowers as established by the European Court of Human Rights. While the European Court of Human Rights takes into consideration the motives of the whistle-blower and the obligation for the whistle-blower to report internally at first, the Directive does not entail the same criteria. Two different and separate approaches on the protection of whistle-blowers are created which may be problematic in the near future.

It remains to be seen whether any Member State will challenge these legal bases in front of the Court, or if the European Commission will propose changes to the legal bases during its review in 2023. Also, future cases in front of the European Court of Human Rights or the CJEU may demonstrate a conflict between the two Courts concerning the requirements for whistleblowers protection. The two years' transposition period will allow for a clearer picture of the way under which the Member States will adapt their national legislation. 